\title{
Benefits of using biogas technology in agricultural area in supporting organic fertilizer for local farmers in Karo district, North Sumatera Province, Indonesia
}

\author{
Nurzainah Ginting ${ }^{1}$, Abdul Rauf ${ }^{1}$
}

\author{
${ }^{1}$ Faculty of Agriculture, University of Sumatera Utara, Indonesia Kampus USU Medan \\ 20155
}

\begin{abstract}
This study has been conducted in an agricultural hilly area of Karo District, in North Sumatera Province, Indonesia. The study was conducted in May until July 2016. The objective of this study is to analyse slurry characteristics as organic fertilizer in which biogas is used to yield better slurries. Five biodigesters were used with 5 differents designs of mix materials: T1) 100\% cow feces, T2) $75 \%$ cow feces $+25 \%$ argicultural waste, T3)50\% cow feces $+50 \%$ agricultural waste, T4) $25 \%$ cowfeces $+75 \%$ agricultural waste, and T5)100\% agricultural waste. The parameters measured were slurry production and slurry chemical compositions including $N, P, K, p H$, and C/N.The result showed that $T 1$ and $T 2$ were better in chemical compositions( $N, P, K, p H$ and $C / N)$ while all treatments produce equal volume of slurry. It is suggested that local farmers use the composition of T1 and T2 when using biogas technology in supporting organic fertilizer. It is noteworthy that this first study is continued with the second one which utilize the resulting slurries of the first on Asparagus and analyse their performance during the period of August to October 2016.
\end{abstract}

Keywords - slurry, agriculture, NPK, $\mathrm{pH}, \mathrm{C} / \mathrm{N}$

\section{Introduction}

Agriculture share on North Sumatera Province GRDP ( Gross Regional Domestic Product) was 23\% in 2015. Horticulture and Crop were dominated; their share were 7.8 and 8.8 respectively compared to livestock, forestry and fishery which were 2.01, 1.12 and 2.75 respectively North Sumatera Province Statistic [1]. Associates with GRDP share of horticulture, as Karo District is an agricultural center area in North Sumatera Province, agricultural industry in Karo District significantly affect GRDP. There is still a chance for agricultural industry in Karo to increase its share on GRDP if agriculture is not mainly depends on land resources. In Karo, farmers are minimize in using technologies and still using conventional methods. Actually Department of Agriculture North Sumatera Province has programs and amongs the programs are improving farmer's welfare and technology application. This research is tried to use a technology which is biogas in supporting farmers. Ginting [2] mentioned that there were three major benefits by using biogas technology, e.i. $\mathrm{CH}_{4}$ as source of renewable energy, slurry as liquid fertilizer and clean environment. Farmers are allowed saving as they dont have to buy karosene or gas for cooking instead they use biogas. Farmers dont have to spend money as usual to buy fertilizer as slurry from biogas is a liquid fertilizer whereas slurry application will reduce chemical fertilizer thus reduce carbon footprints [3]. More over according to Calise et.al. [4] either livestock manure or agro by-product which are utilized for example through biogas technology is ecologically promoting as cleanliness of the environment is one of biogas technology production.

\section{Method}

The study lasted from May until July 2015. The tools used in the research were five-unit installation of biogas 500 liter capacities, a scale to weigh ingredients which will be used in accordance with the treatment and $\mathrm{pH}$ meter to measure $\mathrm{pH}$ of the slurry.

The research materials were cow feces, mix agricultural waste, i.e. local cabbage, chinese cabbage, broccoli, rotten orange and rumen of cow as a starter.

The experimental design used in this research is Completely Randomized Design (CRD) with 5 treatments and 4 repetitions. The treatment in this research is $\mathrm{T} 1=100 \%$ cow feces ; $\mathrm{T} 2=75 \%$ cow feces and $25 \%$ mix agricultural waste ; $\mathrm{T} 3=50 \%$ cow feces and $50 \%$ mix agricultural waste; $\mathrm{T} 4=$ $25 \%$ cow feces and $75 \%$ mix agricultural waste; T5 $=100 \%$ mix agricultural waste. Cow feces and mix agricultural waste were diluted with water in ratio of 1: 2 . Parameters researche were slurry production, and chemical compositions of slurry includes $\mathrm{N}, \mathrm{P}, \mathrm{K}, \mathrm{C} / \mathrm{N}$ and $\mathrm{pH}$. The research of biogas done by filling the biogas digester according to treatment and left for 30 days of HRT (Hydraulic Retention Time) for the gas produced maximum output. Refilling raw ingredients per day is necessary.

\section{Results and Discussion}

\subsection{Slurry Production}

In this research, as the biodigester has a continuos feeding, every day about 9.2 litres substrates were inserted, which means that everyday too 9.2 litres slurry were produced. As fertilizer, bio gas slurry contains of macro nutrients such $\mathrm{N}$, $\mathrm{P}$ and K. Slurry also contains micro nutrients such as $\mathrm{Ca}$, $\mathrm{Mg}, \mathrm{Fe}, \mathrm{Mn}, \mathrm{Cu}$ dan $\mathrm{Zn}$. Bougnom et. al. [5] stated that slurry as fertilizer in liquid form provide nutrition for plant 
easily. Fertilization by slurry on soil improves soil structure, making it easier for plants to absorb nutrients contained inside.

In general, slurry comes from animal waste especially ruminant as only ruminant has methanobacterium which is a key factor in methane production. Ruminant waste itself contain alot of microbes as ruminant digestion process is helped by microbes worked. Almost all the microbes has a positive function unless ruminant are infected by deseases. That is why Yun Cao et.al. [6 [ found that application of bio gas slurry as soil amendment significantly could suppressed soil deseases such as Fusarium. In addition, bio gas slurry significantly reduced population of rhizosphere which is a pathogen microbes. As bio gas materials either feces or agricultural waste are collected locally, so any microbes which developed in slurry also locally and any locally microbes will stand longer in soil. As consequences these microbes become a competitor to any pathogen microbes in soil. More over, microbes population in liquid form could stand longer in soil than microbes in solid form such as compost.

As slurry is a byproduct of bio gas, its prize is very cheap. There has no information about application of slurry cause overdosage so far. In Karo District, in general for one house hold they use a bio gas unit which construct by a thick PE plastic, bio gas unit capacity is 4500 litres and 1500 litres is used as gas container. Another 3000 litres for substrates and because Hydraulic Retention Time is 30 days, so every day 100 litres of substrates are inserted and 100 litres slurry are produced. Because of tremendous volume of slurry, farmers apply slurry in big dosage. For example, coffee farmers in Karo District apply slurry as much as $40 \mathrm{t} / \mathrm{h} / \mathrm{y}$ and sometimes even more. They found that coffee bean size is bigger, so their coffee bean are graded as Premium Class.

Research which was conducted by student of Animal Production, Agriculture Faculty, University of North Sumatera on mix pasture with dosage 20,30 and $40 \mathrm{t} / \mathrm{h} / \mathrm{y}$ showed that $40 \mathrm{t}$ dosage significantly increased fresh mix pasture production of Digitaria milianjana and Clitoria ternatea. Due to the result, it was recommended to increase slurry dosage eventhough in general in tropical land use dosage of organic fertilizer is about $20 \mathrm{t} / \mathrm{h} / \mathrm{y}$.

\section{2. $\mathrm{pH}$}

$\mathrm{pH}$ in this research is range from 4 to $7 . \mathrm{pH}$ is influenced by combination of substrates materials. $\mathrm{pH}$ of biogas slurry is a critical point whether slurry could be used as fertilizer. In this research slurry from T 1, T2, T3 and T4 could be used as liquid fertilizer as according to Standard National Indonesia SNI [7] $\mathrm{pH}$ of liquid fertilizer is range from 4 to 9.

According to Statistic of Karo Distric 2015, agricultural waste in Karo were dominated by local cabbage, chinese cabbage, and rotten orange. That was the reason why those wastes were used as bio gas unit substrates. In addition, because in research location, many farmers grow broccoli so broccoli wastes also were used as substrate. Vegetables have $\mathrm{pH}$ in range of 6.1 to 6.4 while rotten arange has $\mathrm{pH}$ 3.7. Low $\mathrm{pH}$ of rotten orange was the reason for orange wastes used only $25 \%$ of total vegetables waste. $\mathrm{pH}$ of water which was used to dilute materials 7.5.
Eventhough according to SNI 2011 that $\mathrm{pH}$ of fertilizer could be from 4 to 9 how ever field experience showed that ph around 6 until 7 is better in supporting a competation of various microorganism in soil as more various microorganism need ph of 6 to 7 . In order to manage desease in soil the best treatment is by introducing various good microoganisms that could be acted as desease controlled microorganism than by using chemical desease controlled. It was already proved that microbial community in bio gas slurry contained Pseudomonas, Aspergilus sp, Lactobacillus $\mathrm{sp}$ and others Zhao, et.al. [8]. In addition, fermentation of agricultural waste which also were occurred in biodigesters allows microorganism to grow, Lactobacillus $\mathrm{sp}$, for example. Based on these facts, T2 is more likely to be choosed as source of slurry which to be applied as liquid organic fertilizer.

\subsection{N, P, K}

Ginting [2] mentioned that benefits by using biogas technology icludes its slurry as liquid fertilizer which had been proven by research that was conducted by Ginting and Mustamu [9] and they found that application of biogas slurry as $250 \mathrm{ml}$ could be an alternative of $2.5 \mathrm{~g}$ NPK as early fertilizer on the growth of Spinach Plant ( Amaranthus tricolor). Chemical composition of this research is presented in Table 2.

Table 2. Chemical Composition of Biogas Slurry (T2)

\begin{tabular}{|c|c|c|c|}
\hline \multirow{2}{*}{ NO. } & \multirow{2}{*}{$\begin{array}{c}\text { Chemical Quality } \\
\text { Unit }\end{array}$} & \multicolumn{2}{|c|}{ Total } \\
\cline { 3 - 4 } & Slurry & $\begin{array}{c}\text { Liquid Fertilizer } \\
\text { Standard (SNI) }\end{array}$ \\
\hline 1 & N-total (\%) & 1.23 & 1.25 \\
\hline 2 & P2O5 & 0.072 & $>0.05$ \\
\hline 3 & K2O & 0.096 & $>0.05$ \\
\hline 4 & C-organic (\%) & 26 & Min 15 \\
\hline 5 & $\mathrm{C} / \mathrm{N}$ & 20.8 & $15-25$ \\
\hline 6 & $\mathrm{pH}$ & 6 & $4-9$ \\
\hline
\end{tabular}

Source: Central Laboratory, Agriculture Faculty, North Sumatera University 2016

In this research, $\mathrm{N}, \mathrm{P}, \mathrm{K}$ percentage is slight better than Indonesia Liquid Fertilizer Standar (SNI). Eventhough N, $\mathrm{P}, \mathrm{K}$ percentage is small in slurry, but application with high dosage could increase N, P, K content. As mentioned before, in Karo District one unit bio gas with capacity 4500 liter, per day could produce slurry as much as 100 litres per day which equivalent to $1000 \mathrm{~g}$ NPK.. Farmes in Karo used to give high dosage of slurry, for example $40 \mathrm{t} / \mathrm{h} / \mathrm{y}$.

Application of slurry in long term will help farmers in saving by reducing chemical ferlilizer consumption. More over, according to Rattanasuteerakul [10] organic fertilizer allow soil to be conserved and improved farmer's benefit from organic products which has better nutritional value [Sanchez et.al. 11].

\section{4. $\mathrm{C} / \mathrm{N}$}

$\mathrm{C} / \mathrm{N}$ indicates nutrient content and how far degradation process has already taken placed on materials which in this research cow feces and mix agricultural waste. $\mathrm{C} / \mathrm{N}$ in $\mathrm{T} 1$ until T5 were around 21.28 until 18 . T1 was $100 \%$ cow feces which contains $\mathrm{C}$ Organic was 27.24 and Total $\mathrm{N}$ was 1.28 so $\mathrm{C} / \mathrm{N}$ was around 21.28 . T2 was $75 \%$ cow feces and 
$25 \%$ mix waste vegetables where $\mathrm{C}$ organic was 26 and $\mathrm{N}$ was 1.25 so $\mathrm{C} / \mathrm{N}$ was 20.8 . T3 was $50 \%$ cow feces and $50 \%$ mix agricultural waste where $\mathrm{C}$ organic was 25.5 and $\mathrm{N}$ was $1.23 ; \mathrm{C} / \mathrm{N}$ was 20.73 . T4 was $25 \%$ cow waste and $75 \%$ mix agricultural waste, where $\mathrm{C}$ organic was 24.1 and $\mathrm{N}$ was 1.19; $\mathrm{C} / \mathrm{N}$ was 20.25 . T5 was $100 \%$ mix agricultural waste where $\mathrm{C}$ organic was 20.2 and $\mathrm{N}$ was $1.12 ; \mathrm{C} / \mathrm{N}$ was 18 . According to Ginting and Mustamu [9], slurry with $\mathrm{C} / \mathrm{N}$ is high, i.e. more than 20 was suggested to get maturity by keeping the slurry in a container for at least one month. In this time, $\mathrm{N}$ value was getting better as population of microorganism still in form. Microorganism itself contains of amino acid.

\section{Conclusions}

Based on bio gas slurry characteristics as organic fertilizer which were slurry production and slurry chemical compositions including $\mathrm{N}, \mathrm{P}, \mathrm{K}, \mathrm{pH}$, and $\mathrm{C} / \mathrm{N}$ the result showed that biogas slurry characteristics is better than liquid fertilizer standar by Departement of Agriculture of Indonesia. More over, biogas slurry has other utility such as desease controlled. It is suggested that farmers use biogas slurry in their farm practices.

\section{Acknowledgments}

The author gratefully acknowledges that financial support from University of Sumatera Utara.

\section{References}

[1] Statistic of North Sumatera Province 2015.

[2] Ginting, Nurzainah. 2012. Supporting Policy to succeed the Regional Action Plan (RAD) Greenhouse Gas (GHG) emissions in North Sumatra. Innovation: Journal of Politics and Policy. Vol. 9 No. 1, March 2012. ISSN 1829-807.

[3] Soode Eveli, Paul Lampert, Gabriele Weber-Blaschke, Klaus Richter. 2015. Carbon Footprints of the horticultural product strawberries, asparagus, roses and orchids in Germany. Journal of Cleaner Production 87 (2015) 168-179.

[4] Calise, Francesco, Cesare Cremonesi, Giulio de Notaristefani di Vestogirardi, Massimo Dentice d'Accadia. 2015. Technical and Financial analysis of a Cogeneration Plant Fueled by Biogas Produced From Livestock Biomass. Energy Procedia, Volume 82, Pages 666673.

[5] Bougnom B.P, C. Nieder Kofler, B.A. Knapp, E. Stimpfl, H. Ingam. 2012. Residues from renewable energy production: Their value for fertilizing pastures. Biomass and Bioenergy, Vol 39, April 2012, Page 290-295.

[6] Yun Cao, Jidong Wang, Huashan Wu, Shaohua Yan, Dejie Guo, Guangfei Wang, Yan Ma. 2016. Soil Chemical and Microbial Responses to Biogas Slurry Amendment and Its Effect on Fusarium Wilt Suppression. Applied Soil Ecology. Vol 107. September 2016. Pages 116-123.

[7] Standard National of Indonesia. 2011. Department of Agriculture.

[8] Zhao Hong-yan, Jie Li, Jing-jing Liu, Yu-cai Lu, Xiao-fen Wang, Zong-jun Cui. 2013. Microbial Community Dynamics During Biogas Slurry and Cow Manure Compost. Journal of Integrative Agriculture. Vol 126 June 2013. Pages 1087-1097.

[9] Ginting, N and Mustamu, N., 2012. The application of biogas sludge as organic fertilizer on the growth of spinach plant (Amaranthus tricolor).Proceedings. Annual International Conference Syiah Kuala University in 2012 and The $8^{\text {th }}$ IMT-GT Uninet Biosciences Conference. Banda Aceh. 154-156.
[10] Rattanasuteerakul, Kanokporn and Gopal B.Thapa. 2012. Status and finacial performance of organic vegetable farming in northeast Thailand. Land Use Policy. 29 (2012) 456-463.

[11] Sanchez, Maria Terese, Ana Garrido-Varo, Jose-Emilio Guerrero, Dolores Perez-Marin. 2013. Nirs technology for fast authentication of green asparagus grown under organic and conventional production systems. Postharvest Biology and Technology 85 ( 2013) 116-123. 